\title{
Simultaneous Assay of Dihydroxyacetone Synthase and Transketolase in a Methylotrophic Yeast Grown in Continuous Culture. A Cautionary Note
}

\author{
By N. D. LindLEY, M. J. WAITES AND J. R. QUAYLE* \\ Department of Microbiology, The University, Sheffield S10 2TN, U.K.
}

(Received 19 March 1981)

\begin{abstract}
The methylotrophic yeast Candida boidinii CBS 5777 was grown in continuous culture under carbon limitation on glucose, glucose plus methanol, and methanol as carbon and energy sources. During adaptation from glucose to methanol there was a rapid rise in the specific activities of triokinase, fructose-1,6-bisphosphatase and dihydroxyacetone synthase, which are key enzymes of the xylulose phosphate cycle of formaldehyde fixation. The specific activity of classical transketolase fell during this adaptation.

Extracts from carbon-limited C. boidinii contained an enzyme which catalysed oxidation of $\mathrm{NADH}$ when some preparations of ribose 5-phosphate were added, which was not a transketolase. This enzyme activity was dependent on an impurity in such ribose 5-phosphate preparations and can be confused with transketolase activity.
\end{abstract}

\section{INTRODUCTION}

While growing on methanol Candida boidinii has been shown to synthesize two transketolases (Waites \& Quayle, 1981). One is stable, exhibits only classical transketolase activity and is found during growth both on one-carbon and multi-carbon substrates. The other enzyme, which has been given the trivial name dihydroxyacetone (DHA) synthase, is unstable and is only present in cells grown on methanol, where it catalyses a key step in the carbon assimilation cycle (Kato et al., 1979; Waites \& Quayle, 1980, 1981; O‘Connor \& Quayle, 1980). It displays both classical transketolase and DHA synthase activities, i.e. it can use both aldose phosphates (such as ribose 5-phosphate) and formaldehyde as acceptors for the glycolyl group from the donor substrate xylulose 5-phosphate. The measurement of transketolase activity with ribose 5-phosphate as acceptor and xylulose 5-phosphate as donor in crude extracts of methylotrophic yeasts thus results in a composite figure for both enzymes, classical transketolase and DHA synthase, together. We suggested a method for resolving this composite figure into two components for extracts of methanol-grown $C$. boidinii (Waites \& Quayle, 1981). The method consisted of first measuring the DHA synthase activity using formaldehyde as acceptor molecule, then destroying this activity by heat treatment of the crude extract, and finally determining the remaining stable classical transketolase activity using ribose 5-phosphate as acceptor. The present paper describes the use of this technique to examine the activities of key enzymes involved in methanol assimilation during studies with carbon-limited chemostat cultures of $C$. boidinii when the carbon source was changed from glucose to methanol. The study has revealed that certain precautions are necessary when using the simultaneous enzyme assay technique with cells grown under carbon limitation.

\section{METHODS}

Abbreviations. DHA, dihydroxyacetone; DHAP, dihydroxyacetone phosphate; GAP, glyceraldehyde 3phosphate; RiMP, ribose 5-phosphate; TPP, thiamin pyrophosphate; XuMP, xylulose 5-phosphate. 
Organism and growth. Candida boidinii CBS 5777 was grown in carbon-limited chemostat culture (working volume 2.51 ) on the vitamin-supplemented mineral salts medium of van Dijken et al. (1976). The inflowing medium differed only in carbon source, which was either glucose (35 mM) or methanol (210 mM). During the substrate shift it was necessary to employ a mixed substrate (glucose, $7 \mathrm{~mm}$; methanol, $170 \mathrm{~mm}$ ) for a period in order to prevent 'washout' of the culture during adaptation. Cultivation was at $30^{\circ} \mathrm{C}$, the $\mathrm{pH}$ was controlled at 5.0 with $2.5 \mathrm{~mm}-\mathrm{NaOH}$ and the dissolved oxygen was maintained above $60 \%$ saturation. A dilution rate of $0.08 \mathrm{~h}^{-1}$ was used throughout.

Measurement of cell density. Samples of the culture were vacuum-filtered through pre-weighed glass-fibre filters, washed twice with distilled water and dried to constant weight at $105^{\circ} \mathrm{C}$.

Assay of residual substrate. Samples were removed from the chemostat and vacuum-filtered. Methanol was analysed (detection limit $2 \mathrm{mg}^{-1}$ ) with a gas chromatograph equipped with a flame-ionization detector (Pye series 104). A glass column (length $1.8 \mathrm{~m}$ ) packed with Porapak $\mathrm{T}$ (50-80 mesh) was used, with nitrogen as carrier gas and a column temperature of $140^{\circ} \mathrm{C}$. Glucose was assayed (detection limit $1 \mathrm{mg} \mathrm{l}^{-1}$ ) with the GOD Perid-test (Boehringer).

Preparation of extracts. Cell-free extracts of $C$. boidinii were prepared from washed cell paste (obtained by collecting outflow from the chemostat at $0^{\circ} \mathrm{C}$ and centrifuging at $6000 \mathrm{~g}$ for $10 \mathrm{~min}$ ) by ultrasonication (MSE model $150 \mathrm{~W}$ ) at $0^{\circ} \mathrm{C}$ for $5 \times 1 \mathrm{~min}$ in 4 vol. $20 \mathrm{~mm}-\mathrm{KH}_{2} \mathrm{PO}_{4} / \mathrm{NaOH}$ buffer $\mathrm{pH} 7 \cdot 1$. Preparations were centrifuged at $20000 \mathrm{~g}$ for $20 \mathrm{~min}$ at $4{ }^{\circ} \mathrm{C}$ and the supernatants were used as the cell-free extracts.

Enzyme assays. All enzyme assays were carried out at $30^{\circ} \mathrm{C}$ in either a Pye Unicam SP1800 or an SP8-400 double-beam recording spectrophotometer. The term 'classical transketolase activity' is used here for a reaction involving XuMP as glycolyl donor and RiMP as acceptor, whereas DHA synthase activity refers to a reaction in which formaldehyde accepts a glycolyl fragment donated by XuMP.

Classical transketolase (EC 2.2.1.1) was assayed by two procedures. Method $1-$ Cell extract was added to an assay system (final volume $1 \mathrm{ml}$ ) containing: glycylglycine/ $\mathrm{NaOH}$ buffer $\mathrm{pH} 7.6,50 \mathrm{mM} ; \mathrm{MgCl}_{2}, 2 \mathrm{mM}$; TPP, $0.005 \%(\mathrm{w} / \mathrm{v}$ ); NADH, $0.15 \mathrm{~mm}$; RiMP isomerase (EC 5.3.1.6), 1.5 units; ribulose-5-phosphate 3-epimerase (EC 5.1.3.1), 1.5 units; and an excess of a commercial mixture of triosephosphate isomerase (EC 5.3.1.1) and glycerol-3-phosphate dehydrogenase (EC 1.1.1.8) (Boehringer). After assessing NADH oxidase activity an equilibrium mixture of pentose phosphates was generated by the addition of RiMP (initial concentration $5 \mathrm{mM}$ ). Method 2 - This procedure was identical to method 1 except that XuMP was used instead of RiMP to generate a mixture of pentose phosphates and initiate the assay.

DHA synthase activity was determined by monitoring XuMP- and formaldehyde-dependent formation of DHA and GAP as described previously (Waites \& Quayle, 1981). In this assay DHA was converted to DHAP with glycerol kinase (EC 2.7.1.30) and ATP, and the GAP and DHAP were reduced to glycerol phosphate via triosephosphate isomerase, glycerol-3-phosphate dehydrogenase and NADH.

In crude extract, classical transketolase and DHA synthase were determined by the methods mentioned above, and then the extract was incubated at $40^{\circ} \mathrm{C}$ for $10-15 \mathrm{~min}$ to destroy DHA synthase and the remaining stable classical transketolase activity was re-assayed.

Triokinase (phosphorylating DHA) (EC 2.7.1.30), and fructose-1,6-bisphosphatase (EC 3.1.3.11) were assayed by the procedures of van Dijken et al. (1978) and van Dijken \& Quayle (1977), respectively. Triosephosphate isomerase (EC 5.3.1.1) was determined as described by Waites et al. (1981). Ribose5-phosphate ketol-isomerase (EC 5.3.1.6) and ribulose-5-phosphate 3-epimerase (EC 5.1.3.1) were assayed using the methods of Wood (1970). Glycerol-3-phosphate dehydrogenase (EC 1.1.1.8) was determined according to Cooper et al. (1958).

Partial purification of DHA synthase. Cell paste $(20 \mathrm{~g})$ obtained from a methanol-limited chemostat culture of C. boidinii was ultrasonicated as described earlier in 3 vol. $10 \mathrm{mM}-\mathrm{KH}_{2} \mathrm{PO}_{4} / \mathrm{NaOH}$ buffer pH $7 \cdot 1$ containing $0.005 \%(\mathrm{w} / \mathrm{v}) \mathrm{TPP}$, followed by centrifugation at $30000 \mathrm{~g}$ for $15 \mathrm{~min}$ at $4{ }^{\circ} \mathrm{C}$. The supernatant was taken to $50 \%$ saturation with $\left(\mathrm{NH}_{4}\right)_{2} \mathrm{SO}_{4}$ by slow addition of solid $\left(\mathrm{NH}_{4}\right)_{2} \mathrm{SO}_{4}$ at $0{ }^{\circ} \mathrm{C}$. The table of Dawson et al. (1969) was used to compute the quantity required. After equilibration at $0^{\circ} \mathrm{C}$ for $1 \mathrm{~h}$, the mixture was centrifuged $(38000 \mathrm{~g}$, $\left.10 \mathrm{~min}, 0^{\circ} \mathrm{C}\right)$ and the supernatant was taken to $70 \%$ saturation with $\left(\mathrm{NH}_{4}\right)_{2} \mathrm{SO}_{4}$. This mixture was equilibrated and centrifuged as above, and the fraction precipitating between 50 and $70 \%$ saturation was redissolved in $15 \mathrm{ml}$ $5 \mathrm{~mm}-\mathrm{KH}_{2} \mathrm{PO}_{4} / \mathrm{NaOH}$ buffer $\mathrm{pH} 7 \cdot 1$, containing $0.005 \%(\mathrm{w} / \mathrm{v})$ TPP. The sample was applied directly to a column $(10 \times 2 \mathrm{~cm})$ of hydroxylapatite (Biogel HTP, Bio-Rad Laboratories) which had been equilibrated with similar buffer. After the sample had been washed on to the column with a further $30 \mathrm{ml}$ of this buffer it was eluted with a linear phosphate gradient $[10-400 \mathrm{mM}, \mathrm{pH} 7 \cdot 1$, containing $0.005 \%(\mathrm{w} / \mathrm{v}) \mathrm{TPP}]$ made up in $200 \mathrm{ml}$ of the column buffer.

Analytical methods and chemicals. Protein was estimated by the Lowry method using bovine serum albumin as standard. Biochemicals and enzymes were purchased from Boehringer except transketolase, ribulose-5-phosphate 3-epimerase, XuMP and one batch of RiMP, which were from Sigma, and DHA, which was obtained from BDH. The purity of the batches of RiMP from Boehringer and Sigma was 100\% and 99\%, respectively; the XuMP from Sigma was $93 \%$ pure. Formaldehyde was prepared as described previously (Waites \& Quayle, 1981). 
RESULTS AND DISCUSSION

Initial attempts to shift the carbon source of a carbon-limited continuous culture from glucose to methanol were unsuccessful as they resulted in a build-up of residual methanol accompanied by widespread flocculation of the organism, followed by partial lysis and washout. By using a methanol/glucose mixture $(4: 1, \mathrm{w} / \mathrm{w} ; 170 \mathrm{~mm}: 7 \mathrm{~mm})$ for a period prior to growth on methanol alone this problem was largely overcome, although $C$. boidinii still retained a tendency towards filamentous growth. During growth on glucose we achieved growth yields of approximately $95.4 \mathrm{~g}$ dry wt (mol substrate) $)^{-1}$ and on switching to methanol the yield fell to a steady state value of $12.3 \mathrm{~g}$ dry wt (mol substrate) ${ }^{-1}$. In neither steady-state was measurable glucose or methanol present in the culture outflow. Shortly following the shift to a glucose/methanol mixture there was a transient build-up of methanol, which never exceeded $4 \mathrm{~mm}$ and was no longer present $10 \mathrm{~h}$ after the shift.

The activities of the three enzymes specifically involved in methanol assimilation triokinase (phosphorylating DHA), fructose-1,6-bisphosphatase and DHA synthase - were very low during growth on glucose but rapidly increased when methanol became the predominant carbon source (Fig. 1, 2). Within $18 \mathrm{~h}$ of the introduction of methanol into the inflow medium all three enzymes had specific activities which were as high as or higher than those later observed during growth on methanol alone. Triokinase activity initially increased to a level almost twofold greater than that subsequently observed at steady state on methanol.

Egli et al. (1980) found that four dissimilatory enzymes involved in methanol metabolism by Hansenula polymorpha and Kloeckera sp. 2201 became derepressed by varying amounts during carbon-limited growth on glucose. In the present study, however, appreciable derepression of the three assimilatory enzymes did not take place during glucose-limited growth even though the dilution rate employed was low $\left(0.08 \mathrm{~h}^{-1}\right)$. On the other hand, the presence of glucose during the transition to methanol as carbon source did not repress the apparently induced synthesis of the three assimilatory enzymes.

Throughout the shift from glucose to methanol the 'total classical transketolase activity' remained relatively constant (Fig. 2). On introducing methanol as major carbon source an increasing portion of the 'total classical transketolase activity' was actually due to DHA synthase with a corresponding decrease in the contribution made by the stable classical transketolase. Within $18 \mathrm{~h}$ of the switch to a methanol/glucose mixture the 'total classical transketolase activity' was almost equally distributed between the heat-stable classical enzyme and DHA synthase. Little further change occurred as the culture moved to steady state on methanol alone. From these results, superficially it appeared that our simple procedure for determining the contributions made by the stable classical transketolase and DHA synthase to the 'total classical transketolase activity' in crude extracts had been successful. However, further studies revealed unexpected complexities.

Previous studies with batch-grown cells had shown that DHA synthase and classical transketolase were readily separable by hydroxylapatite chromatography (Waites \& Quayle, 1981). When this technique was applied to extracts of cells grown in methanol-limited continuous culture, three peaks of apparent classical transketolase activity were observed (A, $B$ and $C$ in Fig. 3). Peak $C$ also exhibited DHA synthase activity. Peaks corresponding to A and $\mathrm{C}$ had previously been observed with methanol-grown cells from batch cultures (Waites \& Quayle, 1981), but peak B had always been absent or very small. The peak C fractions containing DHA synthase, were pooled and further examined.

In extracts prepared from batch-grown cells on methanol the classical transketolase and DHA synthase activities in the peak corresponding to $\mathrm{C}$ in Fig. 3 had been shown to be unstable, both activities disappearing at the same rate on incubation over a wide range of temperatures (Waites \& Quayle, 1981); this led us to believe that both activities were due to the same enzyme. Similar tests with peak $C$ in Fig. 3 from chemostat-grown cells indicated that classical transketolase activity (as determined by assay method 1 with RiMP initiating the assay) was more stable than DHA synthase activity (XuMP as donor substrate and 


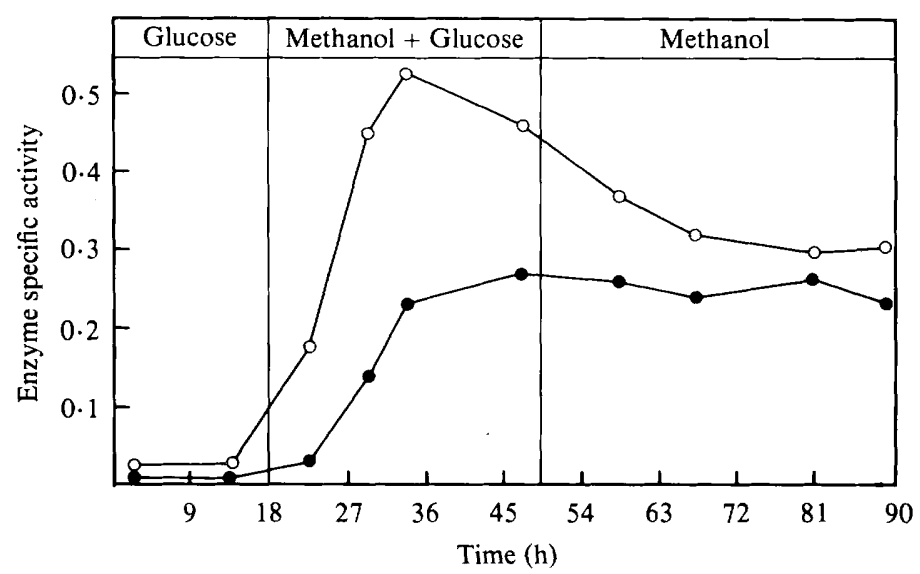

Fig. 1. Changes in the activity of triokinase $(O)$ and fructose-1,6-bisphosphatase $(O)$ in cell-free extracts of $C$. boidinii from a carbon-limited chemostat culture during transition from growth on glucose to growth on methanol. Experimental details are given in Methods. Enzyme specific activities are expressed as $\mu \mathrm{mol}$ substrate consumed $\min ^{-1}$ (mg protein $)^{-1}$.

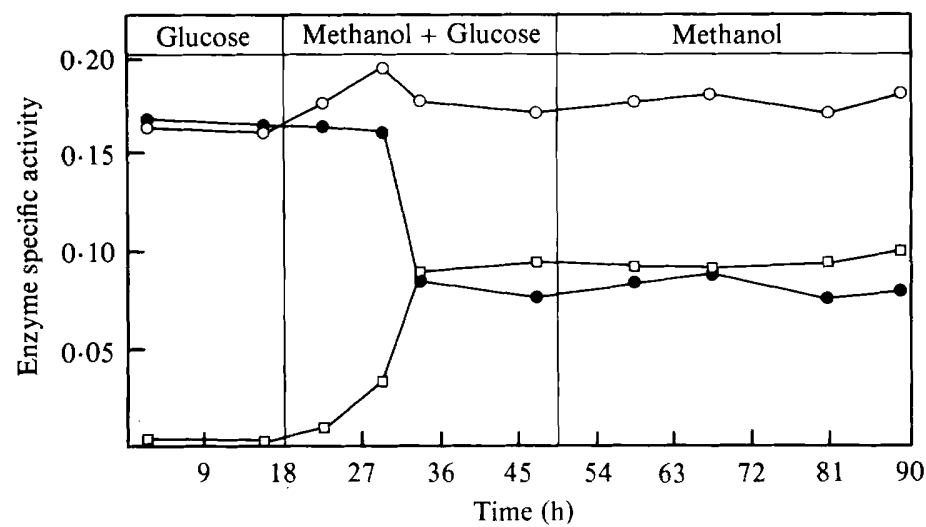

Fig. 2. Changes in the activity of classical transketolase before heat treatment of extract (O), classical transketolase after heat treatment of extract (O) and DHA synthase ( $\square$ ) in cell-free extracts of $C$. boidinii from a carbon-limited chemostat culture during transition from growth on glucose to growth on methanol. Experimental details are given in Methods. Classical transketolase was assayed by method 1. Enzyme specific activities are expressed as $\mu \mathrm{mol}$ substrate consumed $\mathrm{min}^{-1}(\mathrm{mg} \text { protein })^{-1}$.

formaldehyde as acceptor substrate) (Fig. 4). A possible explanation for this was that peak C was contaminated with a relatively stable classical transketolase, probably part of peak B. However, on assaying with XuMP as initiator (assay method 2), classical transketolase activity showed the same instability as DHA synthase (Fig. 4).

The contaminating activity, which accounted for approximately $20 \%$ of the total apparent classical transketolase activity, was re-examined in samples of peak $\mathrm{C}$ after heat-inactivation of DHA synthase. On assaying the preparation for classical transketolase with RiMP (assay method 1) or XuMP (assay method 2) as initiators, the activity was eightfold greater in the former assay than in the latter (Table 1). In either assay an identical mixture of XuMP and RiMP should be generated irrespective of which pentose phosphate was used as initiator. That this was indeed so was confirmed by the demonstration that both assay methods gave the same result for the activity of purified transketolase from bakers' yeast (Sigma) (Table 1). It therefore appeared that the enhanced rate of NADH disappearance observed in assay 


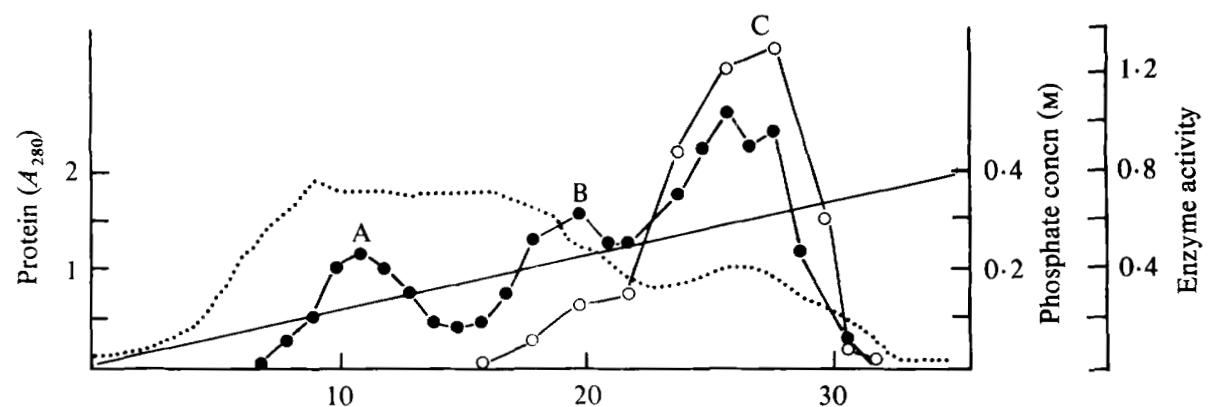

Fraction no.

Fig. 3. Chromatography on hydroxylapatite of a 50-70\% saturation ammonium sulphate fraction from $C$. boidinii grown in methanol-limited chemostat culture. The preparation (containing $190 \mathrm{mg}$ protein) was eluted with a linear phosphate gradient. Samples $(20-50 \mu \mathrm{l})$ of fractions $(5.5 \mathrm{ml})$ were assayed for classical transketolase activity (assay method 1) (O) and DHA synthase activity (O); enzyme activities per fraction are expressed as $\mu \mathrm{mol}$ substrate consumed $\mathrm{min}^{-1}$. Phosphate gradient $(--) ; A_{280}(\cdots)$. Experimental details are given in Methods.

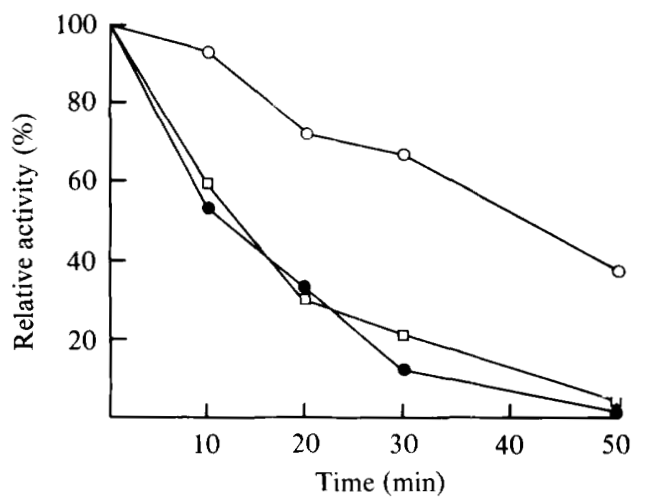

Fig. 4. Thermal stability at $35^{\circ} \mathrm{C}$ of the enzyme(s) contained in peak C from Fig. 3: $\square$, DHA synthase; $O$, classical transketolase activity with RiMP as substrate plus pentose phosphateinterconverting enzymes (assay method 1); - classical transketolase activity with $\mathrm{XuM} P$ as substrate plus pentose phosphate-interconverting enzymes (assay method 2). Experimental details are given in Methods.

\section{Table 1. Variations in transketolase assay}

Samples of peak C from Fig. 3 were heated at $40{ }^{\circ} \mathrm{C}$ for $1 \mathrm{~h}$ to remove DHA synthase activity; the remaining supernatant constituted the transketolase fraction from $C$. boidinii. The transketolase from bakers' yeast was obtained as a purified fraction from Sigma. The transketolase assay methods 1 and 2 are detailed in Methods.

$\begin{array}{lclcc}\text { Assay substrate } & \text { Assay method } & \text { Omissions } & \overbrace{\text { C. boidinii }} & \text { Bakers' yeast } \\ \text { RiMP } & 1 & \text { None } & 100 & 100 \\ \text { XuMP } & 2 & \text { None } & 12.5 & 98.8 \\ \text { RiMP } & 1 & \text { Coupling enzymes* } & 91.8 & 0 \\ \text { XuMP } & 2 & \text { Coupling enzymes* } & 5.2 & 0\end{array}$

* The four coupling enzymes were ribose-5-phosphate isomerase, ribulose-5-phosphate 3-epimerase, triosephosphate isomerase and glycerol-3-phosphate dehydrogenase. 
method 1 as applied to peak $C$ was not due to transketolase activity. This was confirmed by showing that omission of the four coupling enzymes, essential to assay methods 1 and 2 , reduced the rate of RiMP-dependent oxidation of NADH in assay method 1 by less than $10 \%$, whereas omission of these enzymes from assay method 2 resulted in a $60 \%$ decrease in the rate of XuMP-dependent oxidation of NADH (Table 1). The remaining activity could be correlated to demonstrable, low activities of the coupling enzymes in the heat-treated contents of peak C. It followed from this that the RiMP (Sigma, claimed to be $99 \%$ pure) might contain an impurity which served as a substrate for an NADH-linked reductase present in peak $\mathrm{C}$, and, indeed, when $5 \mathrm{mM}$-RiMP was incubated in $50 \mathrm{mM}$-glycylglycine/ $\mathrm{NaOH}$ buffer $\mathrm{pH} 7.6$ with NADH and a sample of heat-treated peak $\mathrm{C}$ a rapid oxidation of $0.05 \mathrm{~mm}-\mathrm{NADH}$ took place and then ceased. After a second addition of $5 \mathrm{~mm}$-RiMP, oxidation of a further $0.05 \mathrm{~mm}-\mathrm{NADH}$ occurred. This suggested that the RiMP contained $1 \%$ of an impurity, active with NADH under these assay conditions. By contrast, a batch of RiMP from Boehringer Biochemicals, claimed to be $100 \%$ pure, showed no such behaviour. When RiMP (Boehringer) was substituted in place of RiMP (Sigma) as assay substrate, the original anomalies noticed in Fig. 4 and Table 1 disappeared and the RiMP and XuMP gave identical activities for classical transketolase by assay methods 1 or 2 .

It should be noted that no such effects using RiMP (Sigma) were observed with the DHA synthase fraction obtained from $C$. boidinii grown under conditions of methanol excess, i.e. batch culture (Waites \& Quayle, 1981). It is therefore clear that the contaminating, $\mathrm{NADH}$-linked reductase present in peak $\mathrm{C}$ must have become derepressed under carbon limitation in the chemostat and given rise to the different behaviour of cell-free extracts obtained from continuous culture as compared with those from batch culture.

The general cautionary note which we wish to emphasize from these results is that an assay, particularly if it is a complex one, may be subject to different interfering activities when applied to crude extracts of substrate-limited cells as compared to extracts of cells grown under substrate excess, due to the presence of a different set of enzymes. In the particular instance detailed in this paper, apparent activities of 'classical transketolase' in Fig. 2 were overestimated by $10-20 \%$. This overestimation can be avoided by using assay method 1 with RiMP which is $100 \%$ pure, or assay method 2 (which is, however, much more expensive in terms of substrate costs).

We thank Dr T. Egli for many helpful discussions and the Science Research Council for support under grant no. GR/A/65966.

\section{REFERENCES}

CoOper, J., Srere, P. A., TABachnick, M. \& RACKER, E. (1958). The oxidative pentose phosphate cycle. II. Quantitative determination of intermediates and enzymes. Archives of Biochemistry and Biophysics 74, 306-314.

Dawson, R. M. C., Elliott, D. C., Elliott, W. H. \& JoNES, K. M. (1969). Data for Biochemical Research, 2nd edn, pp. 615-616. Oxford: Clarendon Press.

Egli, T., van Dijken, J. P., Veenhuis, M., Harder, W. \& FIEChTER, A. (1980). Methanol metabolism in yeasts: regulation of the synthesis of catabolic enzymes. Archives of Microbiology 124, 115-121.

Kato, N., Nishizawa, T., Sakazawa, C., Tani, Y. \& YAMADA, H. (1979). Xylulose 5-phosphate dependent fixation of formaldehyde in a methanol-utilizing yeast Kloeckera sp. no. 2201. Agricultural and Biological Chemistry 43, 2013-2015.
O'Connor, M. L. \& Quayle, J. R. (1980). Pentose phosphate-dependent fixation of formaldehyde by methanol-grown Hansenula polymorpha and Candida boidinii. Journal of General Microbiology 120, 219-225.

van Dijken, J. P. \& Quayle, J. R. (1977). Fructose metabolism in four Pseudomonas species. Archives of Microbiology 114, 281-286.

van Dijken, J. P., Otto, R. \& Harder, W. (1976). Growth of Hansenula polymorpha in a methanollimited chemostat. Physiological responses due to involvement of methanol oxidase as a key enzyme in methanol metabolism. Archives of Microbiology 111, 137-144.

van Dijken, J. P., Harder, W., Beardsmore, A. J. \& QUAYLE, J. R. (1978). Dihydroxyacetone: an intermediate in the assimilation of methanol by yeasts? FEMS Microbiology Letters 4, 97-102. 
Waites, M. J. \& QuAYLe, J. R. (1980). Dihydroxyacetone: a product of xylulose 5-phosphatedependent fixation of formaldehyde by methanolgrown Candida boidinii. Journal of General Microbiology 118, 321-327.

Waites, M. J. \& QuaYle, J. R. (1981). The interrelation between transketolase and dihydroxyacetone synthase activities in the methylotrophic yeast Candida boidinii. Journal of General Microbiology 124, 309-316.
Waites, M. J., Lindley, N. D. \& Quayle, J. R. (1981). Determination of the labelling pattern of dihydroxyacetone and hexose phosphate following a brief incubation of methanol-grown Hansenula polymorpha with $\left[{ }^{14} \mathrm{C}\right]$ methanol. Journal of General Microbiology 122, 193-199.

Wood, T. (1970). Spectrophotometric assay for D-ribose-5-phosphate ketol isomerase and for Dribulose-5-phosphate 3-epimerase. Analytical Biochemistry 33, 297-306. 